\title{
A COMPREHENSIVE ACCOUNT OF SPECIES COMPOSITION, DISTRIBUTION AND ECOLOGY OF PHLEBOTOMINE SANDFLIES IN JORDAN.
}

\author{
KAMHAWI S.*, ABDEL-HAFEZ S.K.* \& MOLYNEUX D.H.**
}

\section{Summary :}

Extensive sampling of 18 localities representing the distinct ecological zones of Jordan was carried out during the sandfly seasons. of 1986 to 1988. This resulted in the collection of 21 sandfly species, 8 of which are reported for the first time from Jordan. The newly reported species include Phlebotomus jacusieli, P. tobbi, P. perfiliewi galilaeus, P. mascitti, P. arabicus, P. halepensis, Sergentomyia palestiniensis and S. taizi. The distribution, relative abundance in domestic and rural sites for all species and the epidemiological significance of Phlebotomus species as vectors of leishmaniases are discussed

KEY WORDS : Phlebotomus. Sergentomyia. climatic zones. Jordan. leishmaniases.

MOTS CLES : Phlebotomus. Sergentomyia. zones climatiques. Jordanie. leish manoises.

\section{INTRODUCTION}

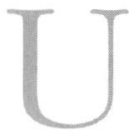

p to date, 13 identified sandfly species were reported from Jordan through preliminary and focal studies (Oumeish et al., 1982; Saliba et al., 1985; Kamhawi et al., 1988; Lane et al., 1988). These included five of the genus Phlebotomus and eight of the genus Sergentomyia. Moreover, specimens belonging to the subgenus Adlerius were reported by Lane et al. (1988). Taking into consideration that zoonotic cutaneous leishmaniasis (ZCL) caused by Leishmania major is endemic in the country (Oumeish et al., 1982; Saliba et al., 1985; Arbagi et al., 1993), and the recent identification of a L. tropica focus from the centre (Saliba et al., 1993) and north of Jordan (Kambawi et al., in press), a more detailed investigation of the species composition, distribution and ecological requirement of sandflies was undertaken through a comprehensive survey of localities representing all the climatic zones of Jordan.

\footnotetext{
* Department of Biological Sciences, Yarmouk University, Irbid, Jordan

** Liverpool School of Tropical Medicine, Liverpool L3 5QA, England.

Correspondence : Dr. Shaden Kamhawi, Assistant Professor, Department of Biological Sciences, Yarmouk University, Irbid, Jordan. Fax : +9626662494- Tel : +9626662494.
}

Résumé : COMPOSITION, DISTRIBUTION ET ÉCOLOGIE DES ESPÈCES DE PHLÉBOTOMES EN JORDANIE

Des récoltes inten sives de Phlébotomes ont été réalisées dans 18 localités réparties dans les différentes zones écologiques de Jordanie, pendant les saisons d'activité des Phlébotomes de 1986 à 1988. Une collection de 21 espèces de Phlébotomes a été obtenue, dont huit rapportées pour la première fois de Jordanie. Les nouvelles espèces récoltées comprennent Phlebotomus jacusieli, P. tobbi, P. perfiliewi galilaeus, P. mascitti, P. arabicus, P. halepensis, Sergentomyia palestiniensis et $\mathrm{S}$. taizi. La répartition, l'abondance relative des espèces dans les sites domestiques et ruraux et la signification épidémiologique des données concernant les Phlebotomus sont discutées, en relation avec leur rôle de vecteur des leishmanioses.

\section{MATERIALS AND METHODS}

ordan is a small country situated at the tip of one of the Red Sea horns. It falls within the Palaearctic region but is also influenced by the Afrotropical region along the Rift Valley system to the extreme west of Jordan. Furthermore, there is the intrusion of Mediterranean elements on the relatively wet northern part of Jordan which decreases further south to be replaced by a dry desert climate.

The Koppen classification model (Anonymous, 1984) divides Jordan into six climatic zones from which 18 localities were chosen to provide a comprehensive survey of all the ecologically distinct regions in the country (Fig. 1).

Sampling of the diverse regions was carried out around the peak of three sandfly seasons (1986 to 1988) and included rural and domestic sites selected from each locality. Rural sites included rocky boulder ranges, open desert, caves and ruins of ancient sites such as amphitheatres and tombs. The domestic sites included mud huts, cement or stone houses, barns for keeping domestic animals (cows, sheep, goats, donkeys and chicken) and rooms used for storage of food. Table I describes the nature of the rural and domestic sites sampled from each of the 18 localities. 


\begin{tabular}{|c|c|c|c|c|c|}
\hline \multirow{2}{*}{$\begin{array}{l}\text { Climatic zone } \\
\text { and sampling sites }\end{array}$} & \multicolumn{3}{|c|}{ Physical parameters ${ }^{2}$} & \multicolumn{2}{|c|}{ Site description } \\
\hline & $\begin{array}{l}\text { Alt } \\
\mathrm{m}\end{array}$ & $\begin{array}{l}\text { MST } \\
\left({ }^{\circ} \mathrm{C}\right)\end{array}$ & $\underset{\%}{\mathrm{MSRH}}$ & Rural & Domestic \\
\hline \multicolumn{6}{|r|}{ I } \\
\hline Ajlun & +1023 & 24 & 50 & $\begin{array}{l}\text { Evergreen Quercus forests, } \\
\text { limestones, terra rosa soil }\end{array}$ & $\begin{array}{l}\text { Inhabited mud huts, food } \\
\text { stores, animal barns }\end{array}$ \\
\hline Shaubak & +1475 & 20 & 40 & $\begin{array}{l}\text { Evergreen Quercus forests, } \\
\text { open scrub land }\end{array}$ & $\begin{array}{l}\text { Inhabited mudhuts, food } \\
\text { stores, animal barns }\end{array}$ \\
\hline \multicolumn{6}{|l|}{ WMC } \\
\hline Irbid & +300 & 26 & 50 & $\begin{array}{l}\text { Deciduous Quercus forests, } \\
\text { open grassland }\end{array}$ & Stone houses \\
\hline Jarash & +640 & 24 & 50 & $\begin{array}{l}\text { Pinus \& Quercus forests, } \\
\text { caves \& ruins }\end{array}$ & Inhabited mud huts \\
\hline Salt & +796 & 24 & 50 & $\begin{array}{l}\text { Brush steppes, grassland, } \\
\text { terra rosa soil, ruins }\end{array}$ & $\begin{array}{l}\text { Inhabited mudhuts, animal } \\
\text { barns }\end{array}$ \\
\hline \multicolumn{6}{|l|}{ CSC } \\
\hline Amman suburbs & +830 & 24 & 48 & $\begin{array}{l}\text { Desert scrub land, } \\
\text { chenopods, rodent } \\
\text { burrows, caves }\end{array}$ & $\begin{array}{l}\text { Inhabited mud huts \& cement } \\
\text { houses, chicken farms }\end{array}$ \\
\hline Petra & +1000 & 24 & 38 & $\begin{array}{l}\text { Limestone \& basalt wadis, } \\
\text { steppe vegetation, caves }\end{array}$ & Not sampled \\
\hline \multicolumn{6}{|l|}{ WSC } \\
\hline Hemmah & -75 & 30 & 50 & $\begin{array}{l}\text { Savannah, rendzina soil, } \\
\text { banana \& date plantations }\end{array}$ & $\begin{array}{l}\text { Inhabited mud huts \& cement } \\
\text { houses, food stores, animal barns }\end{array}$ \\
\hline Um-Quais & +100 & 28 & 50 & $\begin{array}{l}\text { Deciduous Quercus forests, } \\
\text { pastures ruins, caves }\end{array}$ & Not sampled \\
\hline Tabakat Fahl & +400 & 30 & 50 & Agricultural area, caves & Food stores, animal barns \\
\hline \multicolumn{6}{|l|}{ CDC } \\
\hline Mafraq & +580 & 24 & 45 & $\begin{array}{l}\text { Basalt desert, chenopods, } \\
\text { rodent burrows }\end{array}$ & $\begin{array}{l}\text { Inhabited mud huts, animal } \\
\text { barns }\end{array}$ \\
\hline Ras el Naqb & +1570 & 25 & 35 & $\begin{array}{l}\text { Sandy desert, scanty scrub } \\
\text { land, caves }\end{array}$ & Not sampled \\
\hline \multicolumn{6}{|l|}{ WDC } \\
\hline Swainma, Dead Sea & -390 & 30 & 48 & $\begin{array}{l}\text { Sandy desert, chenopods, } \\
\text { rodent burrows }\end{array}$ & $\begin{array}{l}\text { Inhabited mud huts, food } \\
\text { stores, animal barns }\end{array}$ \\
\hline South Shuna & -200 & 30 & 49 & Not sampled & Inhabited mud huts \\
\hline Ghor el Safi & -380 & 30 & 40 & Cultivated scrub land & $\begin{array}{l}\text { Inhabited mud huts \& cement } \\
\text { houses, food stores, chicken farm }\end{array}$ \\
\hline Azraq & +533 & 28 & 40 & $\begin{array}{l}\text { Basalt desert oasis, halophytes } \\
\text { \& chenopods, rodent burrows }\end{array}$ & houses, citrus farm \\
\hline Wadi Rum & +500 & 27 & 30 & $\begin{array}{l}\text { Steep sandy mountains, } \\
\text { chenopods, wild trees \& grasses }\end{array}$ & Not sampled \\
\hline Aqaba & +51 & 30 & 30 & $\begin{array}{l}\text { Sandstone \& granite desert, } \\
\text { chenopods }\end{array}$ & $\begin{array}{l}\text { Inhabited mud huts \& cement } \\
\text { houses, animal barns }\end{array}$ \\
\hline
\end{tabular}

Table I. - Physical parameters and site description of the various localities selected from Jordan

1 Key to climatic zones following Koppen's classification (see Fig. 1).

2 Alt : Altitude ; MST : Mean Seasonal Temperature; MSHR : Mean Seasonal Relative Humidity. The temperature and relative humidity were calculated as means during the sandfly season, July to September (Anonymous, 1984).

\section{COLLECTION OF SANDFLIES}

Sticky paper traps made of A4 sheets of paper and coated with castor oil were the principal method used for the collection of sandflies. The number of sticky traps placed in each site depended on its nature, the diversity of its habitats, and the number of times it was sampled. Aspiration and CDC miniature light traps were occasionally used in houses and caves.

\section{IDENTIFICATION OF SANDFLIES}

Sandflies were identified according to the keys of Theodor (1958), Perfil'ev (1968), Lewis (1973, 1982), Lewis and Buttiker (1982), Lane and Al-Taqi (1983) and Lane (1986).
The dissection of the base of the spermatheca is required to distinguish between females of $P$. tobbi and P. perfiliewi galilaleus (Léger et al., 1983). As the males are easily distinguishable, the females were grouped together and the number of males were relied upon to reflect the abundance of each species in a locality. Furthermore, due to the difficulty of distinguishing males of some Sergentomyia species, $S$. antennata, S. theodori and S. fallax were grouped together as $S$. antennata complex (Lane et al., 1988) and those of $S$. clydei and S. adleri as ad/cl. 


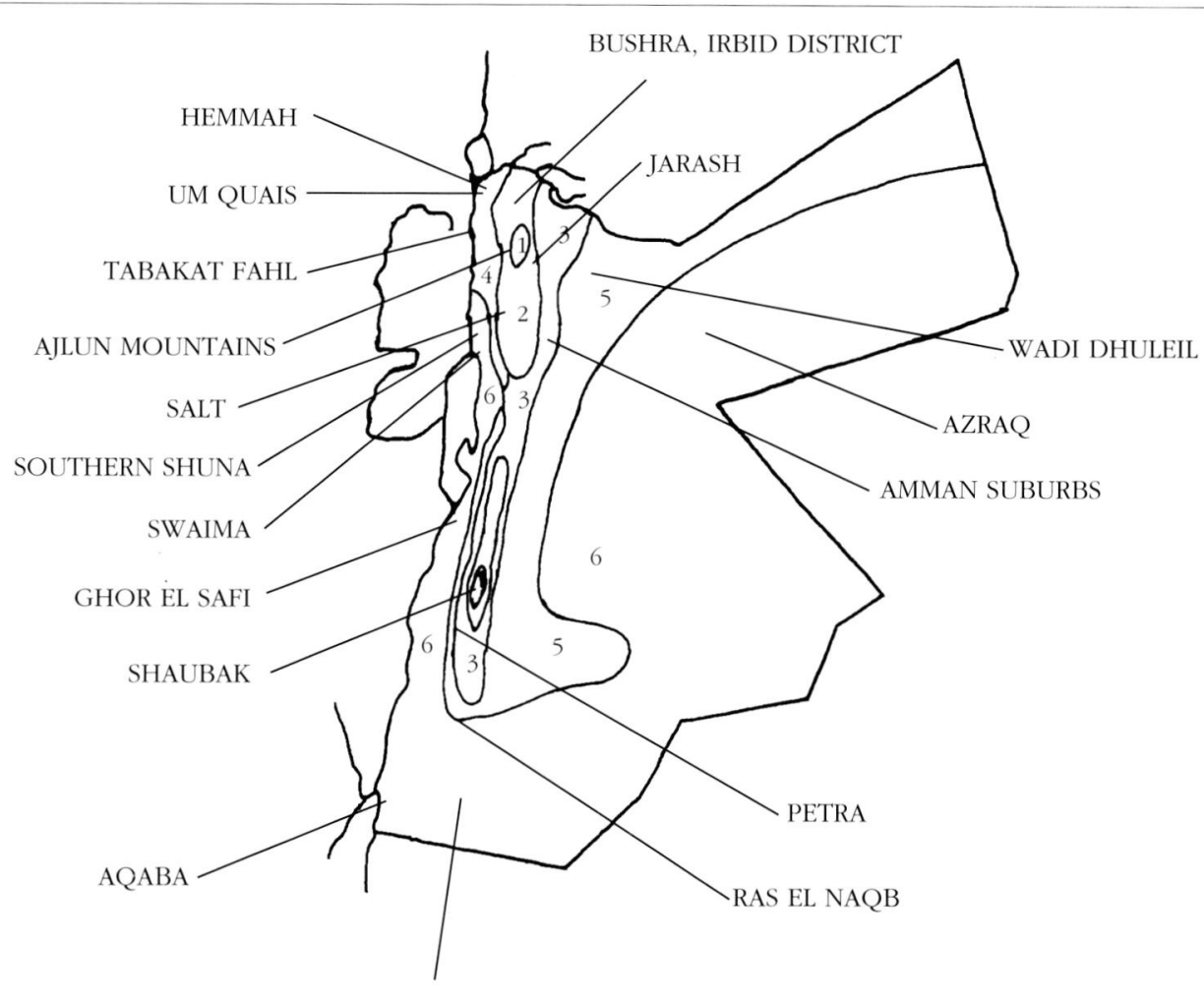

WADI RUM

Fig.1. - Distribution of the eighteen sampled sites within the six climatic zones of Jordan (Koppen's classification model, for information on the climatic zones see Lane et al, 1988). Key to climatic zones : 1 Cool Mediterranean Climate 2 Warm Mediterranean Climate 3 Cool Steppe Climate 4 Warm Steppe Climate 5 Cool Desert Climate 6 Warm Desert Climate

\section{RESULTS}

ome 26582 sandflies were collected throughout this study from domestic and rural sites of 18 localities distributed throughout Jordan. A total of 21 species were identified, 11 Phlebotomus spp. and 10 Sergentomyia spp. Of these, 8 species are recorded for the first time from Jordan : Phlebotomus jacusieli, P. tobbi, P. perfiliewi galilaeus, P. mascitti, $P$. arabicus, $P$. halepensis, Sergentomyia palestiniensis and S. taizi.

The Phlebotomus and Sergentomyia species composition differed from one locality to another reflecting changes in the environment from north to south and from west to east. Overall, P. papatasi and P. sergenti and the $S$. antennata complex were collected from all zones (tables II and III). Members of the subgenus Larroussius were predominant in the Mediterranean influenced sites in the north while Afrotropical species such as $S$. africana were present only along the narrow strip of the Rift Valley system along the western border of the country. Jarash, Salt, Petra, Tabakat Fahl and Ras el Naqb are considered transitional localities as they are influenced by two zones (Fig. 1).
The sandfly fauna in these localities is rich and often included species known from dry desert areas such as P. kazeruni as well as Mediterranean species such as P. major syriacus.

Males of the Phlebotomus species were collected in significantly larger numbers than females from most of the sites sampled (table IV). The overall male to female ratio was highest for $P$. major syriacus and lowest for P. tobbi/perfiliewi galilaeus. This observation was not applicable to Sergentomyia species where the male to female ratio was variable (table V). For example, more males than females were collected for $S$. christophersi and the reverse was noted for $S$. africana. Moreover, there was no consistency observed in the male to female ratio for the same species when collected from different localities (table V).

\section{COMMENTARY ON THE DISTRIBUTION AND ECOLOGY OF COLLECTED SPECIES}

Figs. 2, 3 and 4 show the relative abundance of the predominant species collected from domestic and rural habitats within productive sites.

$P$. papatasi was most predominant in the Jordan Valley, in sites such as Hemmah, Swaima and 


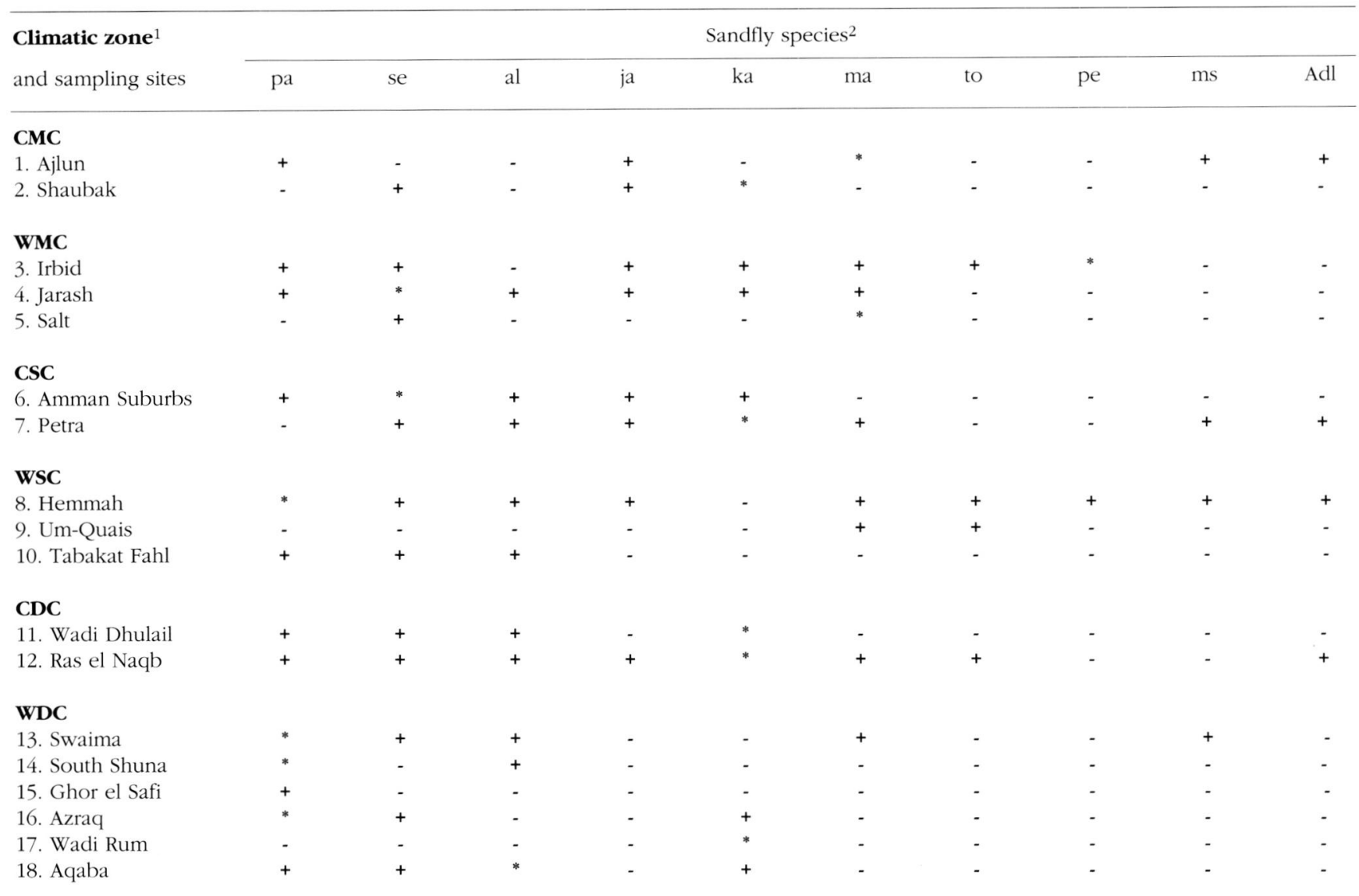

Table II. - Distribution of Phlebotomus species collected from 18 sampling sites in Jordan. (* indicates the most abundant species). 1 Key to climatic zones following Koppen's classification (see Fig. 1).

2 Key of sandfly species: pa, Phlebotomus papatasi; se, P. sergenti; al, P. alexandri; ja, P. jacusieli; ka, P. kazeruni; ma, P. major syriacus; to, P. tobbi; pe, P. perfiliewi galilaeus, ms, P. mascitti; Adl, P. arabicus and P. halepensis.

Southern Shuna. It was also abundant in some localities endemic for ZCL such as the suburbs of Amman but rare from the very arid sites such as Ras el Naqb which is distant from human habitation and supports only scanty vegetation. Although $P$. papatas $i$ was collected from both domestic and rural habitats (Figs. 2, 3 and 4), it was more abundant in domestic habitats from the sites where it was dominant, such as Hemmah and Swaima.

$P$. sergenti represented a small proportion of the total catch in 11 out of 13 sites (table II, Figs. 2 and 4). It was the dominant Phlebotomus species in the suburbs of Amman and was abundant in Jarash. The low density of this species has been observed by many workers (Buttiker and Lewis, 1979, 1983; Dedet et al., 1984). Although $P$. sergenti is known to be highly anthropophilic, it was collected from both domestic and rural sites from the suburbs of Amman (Fig. 4) and only from rural habitats in Jarash (Fig. 2). This exophilic behaviour was also observed in collections from Algeria (Dedet et al., 1984).

$P$. alexandri has a fairly wide distribution in Jordan. It was collected from both domestic and rural habitats of all zones apart from the CMC (table II). It was relatively abundant in Swaima and Aqaba where it was the dominant Pblebotomus species (Fig. 3). Its abundance appeared to correspond to areas where the African Acacia trees are present supporting the reports of Lewis and Buttiker (1980, 1986).

$P$. jacusieli, reported for the first time from Jordan, showed a wide distribution range. It was well represented in the suburbs of Amman, rare in Ras el Naqb and absent from the rest of the eastern and western desert sites (table II and Fig. 4). This species was reported from hilly mountainous areas in Iran and Israel (Theodor and Meshgali, 1964; Warburg, 1986; Lane et al., 1988).

P. kazeruni is common in Jordan and was collected from 10 sites. It was abundant from the dry desert sites in the east and south particularly in Ras el Naqb. Furthermore, it was the dominant Phlebotomus species in Petra and Wadi Dhuleil and the only Phlebotomus species collected from Wadi Rum (table II and Fig. 4).

Typical Eastern Mediterranean fauna such as Phlebotomus major syriacus, $P$. tobbi and $P$. perfiliewi 
Ajlun

Total : 2666
Irbid

Total : 3794
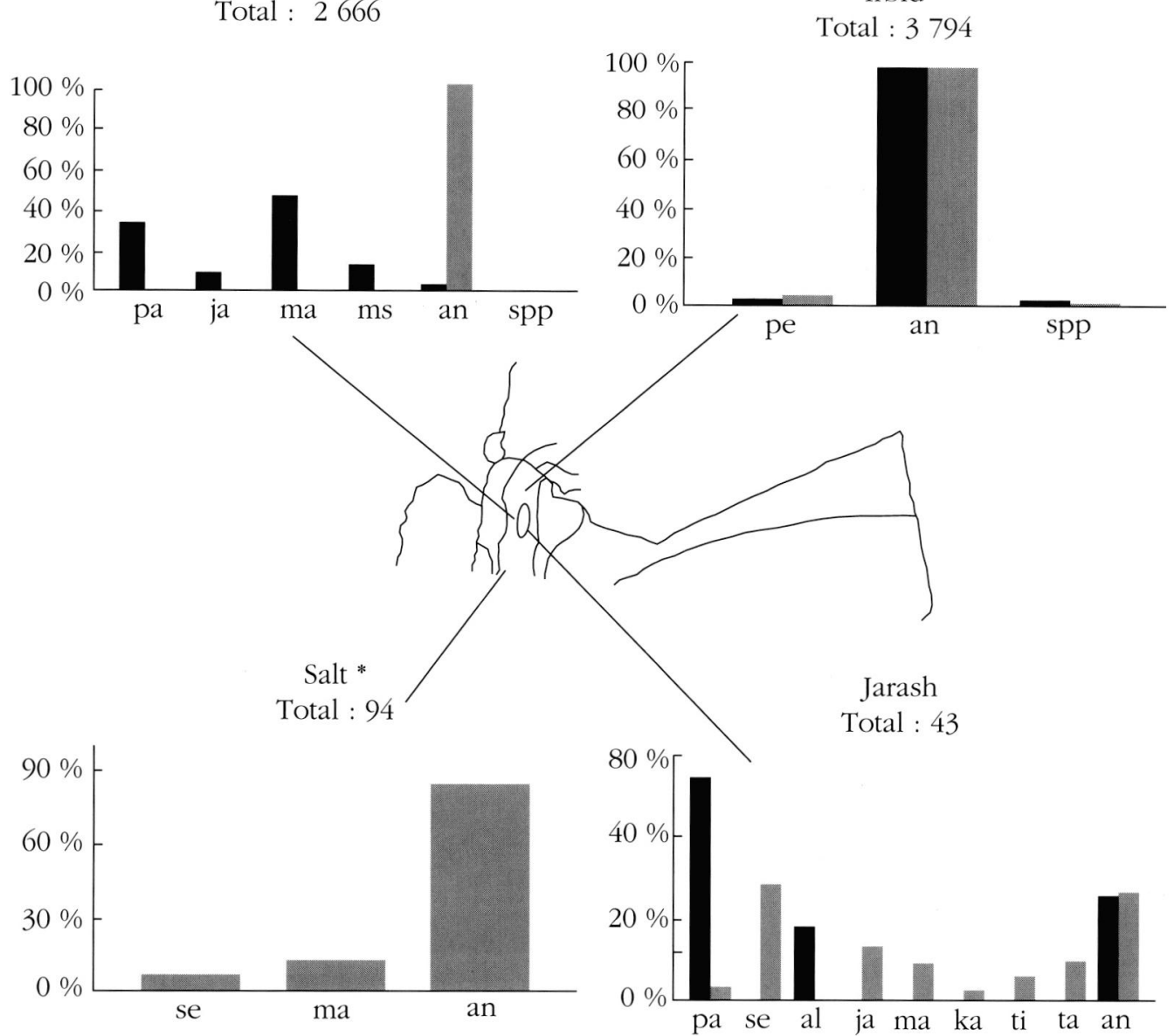

Jarash

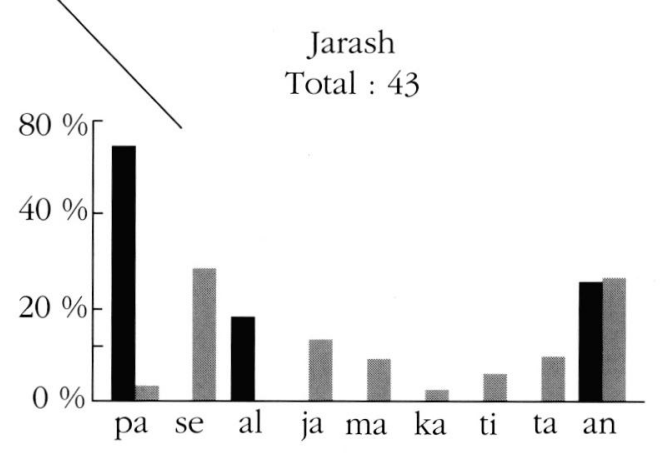

Fig. 2. - The relative abundance of the dominant species collected from productive sites situated within the Mediterranean influenced nor-

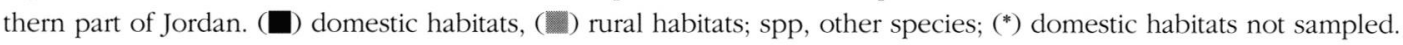
Key to species code is given in Tables II and III.

galilaeus of the subgenus Larroussius as well as $P$. arabicus and $P$. halepensis of the subgenus Adlerius, were well represented from the north of Jordan and were rare or absent from the desert zones (table II).

Phlebotomus major syriacus was the dominant Phlebotomus species in Ajlun Mountains and Salt (Fig. 2) where it was collected from both domestic and rural habitats. This species is usually found in rocky areas of high altitude and water table (Buttiker and Lewis, 1983; Lane et al., 1988). In Jordan, it was abundant in lowlands such as Hemmah $(75 \mathrm{~m}$ below sea level) as well as highlands such as Ajlun Mountains (1023m above sea level) indicating that altitude is of little importance in restricting the spatial distribution of this species.

P. tobbi and P. perfiliewi galilaeus, reported for the first time from Jordan, were mostly restricted to sites situated in the WMC and WSC such as Irbid, Hemmah and Um-Quais (table II). They were rare in most of the collections apart from Irbid where $P$. perfiliewi galilaeus was the dominant Phlebotomus species and was collected in relatively large numbers indoors (Fig 2). P. mascitti, P. halepensis and P. arabicus also reported for the first time from Jordan, were collected in very small numbers from rural and domestic habitats in five sites belonging to different zones (table II). The Sergentomyia antennata complex, which consists of $S$. antennata, S. theodori and S. fallax, was the predominant Sergentomyia spp. present in Jordan. These species were collected in large numbers from both rural and domestic habitats of all the localities sampled apart from Shaubak and Um-Quais (table III, Figs. 2, 3 and 4).

S. africana is an afrotropical species and was restricted in its distribution to the western strip of the Rift Valley system in Jordan (table III). It was most abundant in rural and domestic habitats in Swaima, a dry arid desert which supports some Chenopods and sparse Acacia trees (Fig. 3). It was also common in El-Hemmah, which represents a different biotope from Swaima and is a humid area with dense agricultural vegetation. 


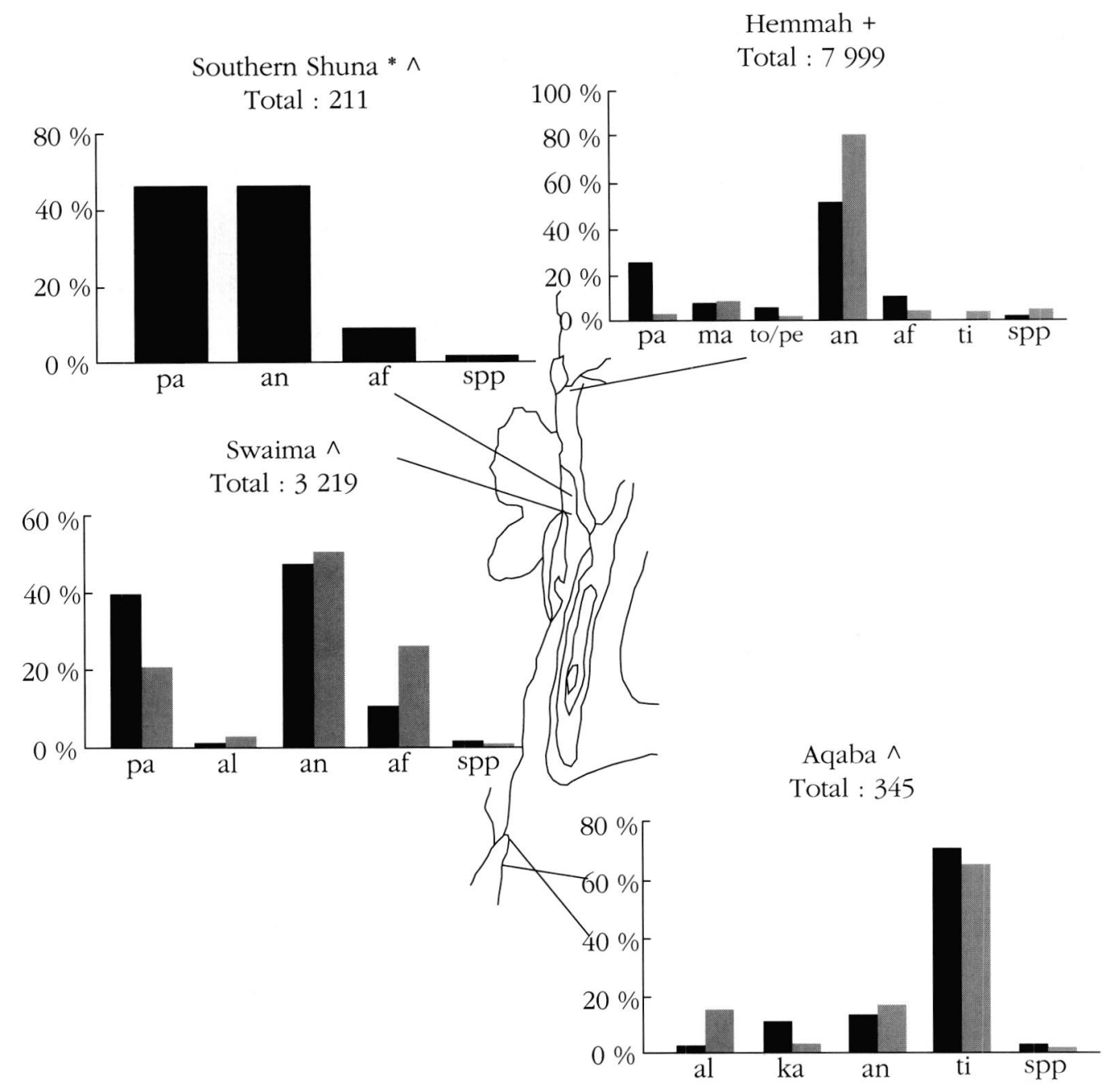

Fig. 3. - The relative abundance of the dominant species collected from productive sites located along the African Rift Valley Strip in the west of Jordan. ( $)$ domestic habitats, ( $\mathbf{\square})$ rural habitats; spp, other species; $\left(^{*}\right)$ rural habitats not sampled; $(+)$ site influenced by the Mediterranean climate; $(\wedge)$ site influenced by the desert climate. Key to species code is given in tables II and III.

S. tiberiadis was collected from both Mediterranean zones such as Jarash and Hemmah and desert zones such as Aqaba and Wadi Rum (Figs. 2, 3 and 4). It was more abundant in desert zones and was the most dominant species in Aqaba.

S. christophersi was collected from five sites, most of which were dry and arid (table III). It was rare in most of the collections except Wadi Rum where it was the most dominant sandfly species (Fig. 4).

S. adleri and S. clydei were collected in small numbers from Hemmah and Ghor el Safi situated along the Rift Valley and Ras el Naqb in the eastern desert (table III). Both are considered as afrotropical species (Theodor and Meshgali, 1964; Buttiker and Lewis,
1983; Lane and Al-Taqi, 1983). These species were reported earlier from Aqaba (Kamhawi et al., 1988).

$S$. taizi was collected in low numbers from both desert and Mediterranean zones and although it is known as a typically high altitude species (Buttiker and Lewis, 1983), it was collected from Hemmah and Swaima at altitudes of $75 \mathrm{~m}$ and $390 \mathrm{~m}$ below sea level respectively (table III).

S. palestiniensis was collected in very small numbers from Hemmah, Swaima and Petra (table III). It has been reported from Israel, Iraq, Iran, Saudi Arabia and Egypt (Lane, 1986) and was therefore expected to be present in Jordan (Lane et al., 1988). 
Amman Suburbs

Total : 6818
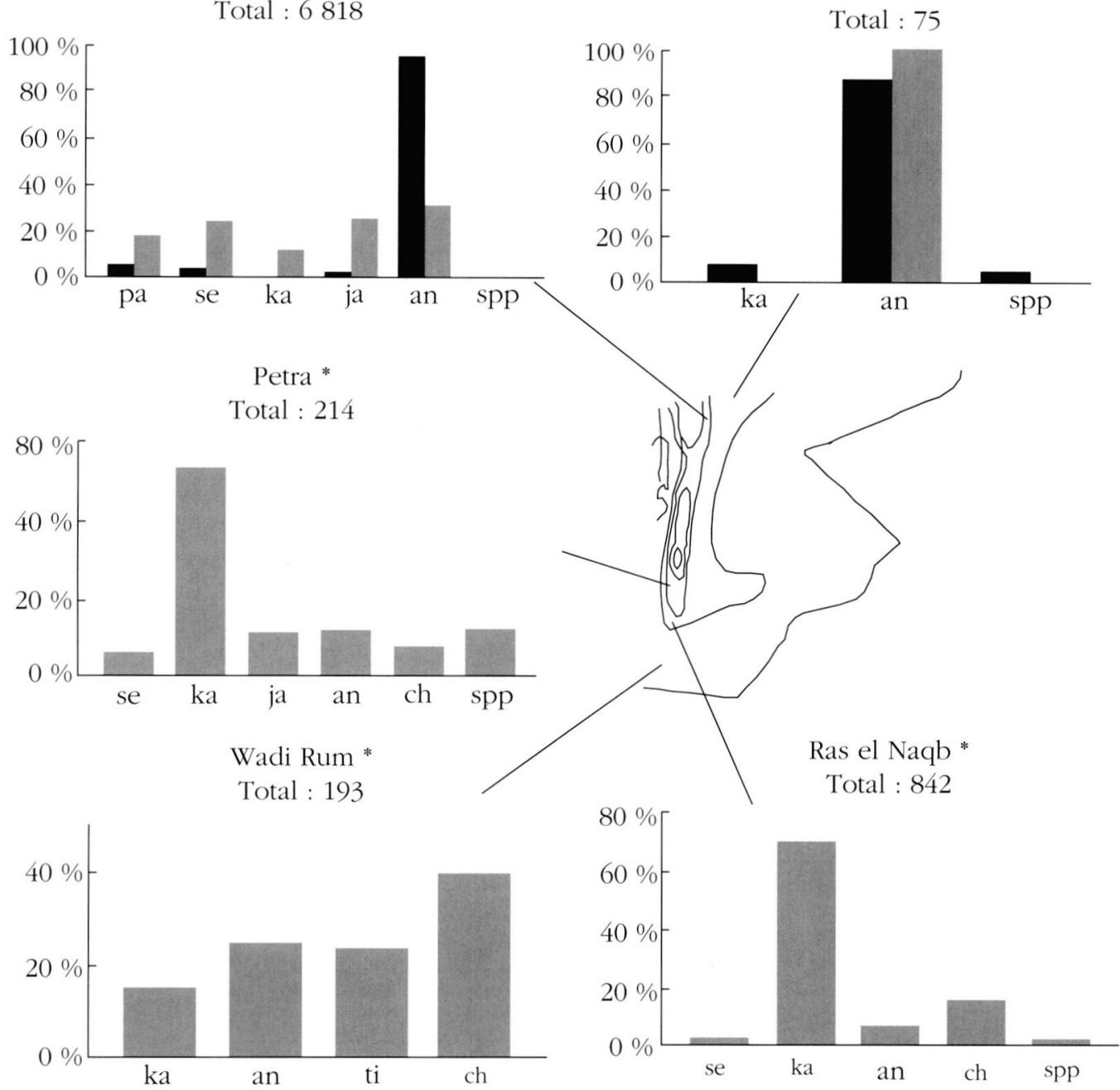

Fig. 4. - The relative abundance of the dominant species collected from productive sites situated in the eastern highlands and desert of Jordan. (ם) domestic habitats, (相) rural habitats; spp, other species; $(*)$ domestic habitats not sampled. Key to species code is given in tables II and III.

\section{DISCUSSION}

\section{ECOLOGICAL CONSIDERATIONS}

Tordan, although a small country, supports a rich sandfly fauna. Some 16 out of the 21 species collected from Jordan were present in Hemmah making it the most versatile of all the sites sampled (table II). Despite being a low altitude locality (ca $75 \mathrm{~m}$ below sea level) it has produced typically high altitude species such as $P$. major syriacus which was the most abundant Phlebotomus species present apart from P. papatasi (Fig 3). This diversity may be a reflection of the rocky nature and the warm and humid climatic conditions of this area combined with the influence of both the Mediterranean and
Afrotropical Rift Valley elements. Jarash, Petra and Ras el Naqb also exhibited a rich sandfly fauna (table II). All of these are transitional sites which are influenced by two zones. This is reflected in their sandfly fauna whereby typical desert species such as $P$. kazeruni and typical Mediterranean species such as P. major syriacus were collected from the same site. Ajlun Mountains represented an interesting site in terms of the discrete division observed in the distribution of its sandfly species in domestic and rural habitats (Fig. 2). There, Phlebotomus species were almost restricted to domestic habitats and Sergentomyia antennata to rural ones.

Jordan seems to represent the extreme of the distribution range for some species such as $P$. perfiliewi gali- 
Climatic zone ${ }^{1}$

and sampling sites
Sandfly species ${ }^{2}$

an $\quad$ af $\quad$ ti $\quad$ ch $\quad \mathrm{ad} / \mathrm{cl} \quad$ ta $\quad \mathrm{pl}$

\section{CMC}

1. Ajlun

2. Shaubak

WMC

3. Irbid

4. Jarash

5. Salt

CSC

6. Amman Suburbs

7. Petra

\section{WSC}

8. Hemmah

9. Um-Quais

10. Tabakat Fahl

\section{CDC}

11. Wadi Dhuleil

12. Ras el Naqb

\section{WDC}

13. Swaima

14. South Shuna

15. Ghor el Safi

16. Azraq

17. Wadi Rum

18. Aqaba

Table III. - Distribution of Sergentomyia species collected from 18 sampling localities in Jordan. (* indicates the most abundant species). 1 Key to climatic zones following Koppen's classification (see Fig. 1).

2 Key of sandfly species: an, Sergentomyia antennata complex including S. antennata, S. theodori and S. fallax; af, S. africana; ti, S. tiberiadis; ch, S. christophersi; ad/cl, S. adleri and S. clydei; ta, S. taizi; $\mathrm{pl}$, S. palestiniensis.

\begin{tabular}{|c|c|c|c|c|c|c|c|}
\hline \multirow{2}{*}{$\begin{array}{l}\text { Sampling } \\
\text { sites }\end{array}$} & \multicolumn{7}{|c|}{ Sandfly species } \\
\hline & pa & se & al & ka & ja & $\mathrm{ma}$ & to/pe \\
\hline Ajlun & & & & & & $13: 0$ & \\
\hline Shaubak & & $4: 0$ & & $5: 1$ & & & \\
\hline Jarash & $6: 1$ & $8: 1$ & & & & & \\
\hline Salt & & $2: 1$ & & & & $11: 0$ & \\
\hline Amman Suburbs & $8: 1$ & $1: 2$ & & $1: 2$ & 10:0 & & \\
\hline Petra & & $2: 1$ & & $10: 1$ & $1: 1$ & $7: 1$ & \\
\hline Hemmah & $4.6: 1$ & 1.6:1 & $18: 1$ & & & $3: 1$ & $2: 1$ \\
\hline Ras el Naqb & & $18: 1$ & & $7.5: 1$ & & & \\
\hline South Shuna & $3: 1$ & & & & & & \\
\hline Swaima & $2: 1$ & & 2.6:1 & & & & \\
\hline Wadi Rum & & & & $27: 1$ & & & \\
\hline Aqaba & & & $5: 0$ & $8: 1$ & $20: 1$ & & \\
\hline Overall & $4.7: 1$ & $5.9: 1$ & $9.5: 1$ & $10.7: 1$ & $11: 1$ & $17: 1$ & $2: 1$ \\
\hline
\end{tabular}

Table IV. - The male : female ratio for the dominant Phlebotomus species collected from productive sites in Jordan. (Code of sandfly species as in Table II). 


\begin{tabular}{|c|c|c|c|c|c|c|}
\hline \multirow{2}{*}{$\begin{array}{l}\text { Sampling } \\
\text { sites }\end{array}$} & \multicolumn{6}{|c|}{ Sandfly species } \\
\hline & an & af & $\mathrm{ti}$ & ch & $\mathrm{ad} / \mathrm{cl}$ & $\mathrm{ta}$ \\
\hline Ajlun & $1: 1$ & & & & & \\
\hline Irbid & $1: 3.8$ & & & & & \\
\hline Jarash & $3: 1$ & & & & & \\
\hline Salt & $1: 1.6$ & & & & & \\
\hline Amman Suburbs & $1: 2$ & & & & & \\
\hline Petra & $1.4: 1$ & & & $7.5: 1$ & & $1: 3$ \\
\hline Hemmah & $1: 3.4$ & $1: 1.3$ & $1: 1$ & & $2.6: 1$ & \\
\hline Tabakat Fahl & $1: 1$ & & & & & \\
\hline Wadi Dhuleil & 1:8.6 & & & & & \\
\hline Ras el Naqb & $6: 1$ & & & $1: 1$ & & \\
\hline Azraq & $1: 1$ & & & & & $4: 1$ \\
\hline South Shuna & $1: 2$ & $1: 8$ & & & & \\
\hline Swaima & $2.6: 1$ & $1: 1$ & $4: 1$ & & & \\
\hline Wadi Rum & $5: 1$ & & $1: 1$ & $1.8: 1$ & & \\
\hline Aqaba & $2.8: 1$ & & $2.8: 1$ & & & \\
\hline Overall & $1: 1$ & $1: 3.4$ & $2.2: 1$ & $3.4: 1$ & $2.6: 1$ & $1.3: 1$ \\
\hline
\end{tabular}

Table V. - The male : female ratio for the dominant Sergentomyia species collected from productive sites in Jordan. (Code of sandfly species as in Table III).

laeus and P. jacusieli whose present record from Jordan represents the eastern limit of their distribution range.

As for the sex ratio of sandflies throughout the collections, Phlebotomus species showed a greater male to female ratio (table IV). This ratio was variable for Sergentomyia species being biased towards the reverse (table V). This may be a reflection of the attraction of Phlebotomus males to sticky traps which were the main method of sampling used in this investigation.

\section{EPIDEMIOLOGICAL CONSIDERATIONS}

$P$. papatasi was recently incriminated as the vector of L. major in the Jordan Valley (Janini et al., in press). In the present study, it was found to be the dominant Phlebotomus species in sites such as Swaima and Southern Shuna in the Jordan Valley which is known for its hyperendemicity to ZCL (Arbagi et al., 1993). It was also abundant in the suburbs of Amman from an area where a ZCL outbreak caused by L. major ocurred in 1982-1983 (Saliba et al., 1985). Therefore, this species is suspected of being the vector of $L$. major throughout the country. This is supported by the fact that it is a proven vector of this parasite in surrounding countries such as Israel (Schlein et al., 1982) and Saudi Arabia (Killick-Kendrick et al., 1985).

$P$. sergenti is the principal vector of $L$. tropica in the Old World (Killick-Kendrick, 1990). L. tropica has been recently identified from foci in the centre (Saliba et al., 1993) and north of Jordan (Kamhawi et al., in press). The collection of $P$. sergenti from several sites sampled during this study including Salt, the area from where L. tropica was identified (Saliba et al., 1993), is indicative of the epidemiological importance of this species which is thought to be the vector of $L$. tropica in Jordan.

$P$. major neglectus, a closely related species to $P$. major syriacus, is a proven vector of visceral leishmaniasis in the Mediterranean Basin (Killick-Kendrick, 1990). Recently, canine visceral leishmaniasis has been reported from Israel with $P$. major syriacus as its proven vector (Jaffe et al., 1988). Information available on the true situation in Jordan with respect to the presence and incidence of visceral leishmaniasis is lacking. The abundance of $P$. major syriacus in several sites from Jordan; its tendency towards endophilic behaviour in some; the availability of resting and breeding sites in domestic habitats and the presence of possible reservoirs such as dogs make Jordan vulnerable to the introduction of visceral leishmaniasis.

$P$. perfiliewi was incriminated as the vector of a dermotropic strain of $L$. infantum which causes cutaneous leishmaniasis in the Mediterranean Basin (Maroli et al., 1987). Therefore, P. perfiliewi galilaeus, which was found to be the dominant Phlebotomus species in Irbid and which seems to be endophilic in its behaviour, can be of epidemiological importance in Jordan. 


\section{ACKNOWLEDGEMENT}

$T$ his work received financial support from Yarmouk University Research Council.

\section{REFERENCES}

ANonymous National Atlas of Jordan. 1 : Climate and Agroclimatology. Jordan National Geographic Center, 1984, $135 \mathrm{p}$.

arbaji A.K., Gradoni L. \& Gramiccia M. Leishmanin skin test survey in a focus of high endemicity of Leishmania major in Jordan. Acta Tropica, 1993, 54, 77-79.

ButTiker W. \& Lewis D. J. Ecological studies at Hofuf, eastern Saudi Arabia, in relation to dermal leishmaniasis. Tropenmedizin und Parasitologie, 1979, 30, 220-229.

Buttiker W. \& Lewis D. J. Some ecological aspects of Saudi Arabian sandflies (Diptera : Psychodidae). Fauna of Saudi Arabia, 1983, 5, 479-530.

Dedet J.P., Addaki K. \& Belazzoug S. Les Phlébotomes (Diptera : Psychodidae) d'Algérie. Cabiers O.R.S.T.O.M., Series of Entomological and Medical Parasitology, 1984, 22, 99-127.

Jaffe C.L., Keren E., Nahary O., Rachamim N. \& Schnur L. Canine visceral leishmaniasis at Wadi Hamam, in Israel. Transactions of the Royal Society of Tropical Medicine and Hygiene, 1988, 82, 852-853.

Janini R., Saliba E., Khouri S., Oumeish O., Adwan S. \& Kamнawi S. Incrimination of Phlebotomus papatasi as vector of Leishmania major in the southern Jordan Valley, Jordan. Medical and Veterinary Entomology (in press).

Kamhawi S., AbDel-Hafez S. K. \& Arbagy A. A new focus of cutaneous leishmaniasis caused by Leishmania tropica in northern Jordan. Transactions of the Royal Society of Tropical Medicine and Parasitology, 1995 (in press).

Kamhawi S., Abdel-Hafez S. K., Lane R. \& Molyneux D. H. Ecology and distribution of sandflies (Diptera : Psychodidae) in Aqaba District, South Jordan. Fauna of Saudi Arabia, 1988, 9, 83-89.

KILLICK-KENDRICK R. Phlebotomine vectors of leishmaniases : a review. Medical and Veterinary Entomology, 1990, 4, 1-24.

Killick-Kendrick R., Leaney A. J., Peters W., Rioux A.J. \& BraY R.S. Zoonotic cutaneous leishmaniasis in Saudi Arabia : the incrimination of $P$. papatasi as the vector in the Al-Hassa Oasis. Transactions of the Royal Society of Tropical Medicine and Hygiene, 1985, 79, 252-255.

Lane R.P. The sandflies (Diptera : Phlebotominae) of Egypt. Bulletin of the British Museum, Natural History (Entomology), 1986, 52, 1-35.

Lane R. P. \& Al-Taer M. Sandflies (Diptera : Psychodidae) and leishmaniasis in Kuwait. Bulletin of Entomoligal Research, 1983, 73, 633-644.

Lane R.P., AbDel-Hafez S. \& Kamhaw S. The distribution of phlebotomine sandflies in the principal ecological zones of Jordan. Medical and Veterinary Entomology, 1988, 2, 237-246.
Léger N., Pesson B., Madulo-Leblond G. \& Abonnenc E. Sur la différenciation des femelles du sous-genre Larroussius Nitzulescu, 1931 (Diptera : Psychodidae) de la région méditerranéenne. Annales de Parasitologie Humaine et Comparée, 1983, 58, 617-623.

LEwis D. J. Phlebotomidae and Psychodidae, in : Insects and other arthropods of medical importance, Smith K.G.V. (ed.), London, 1973, 159-179.

LEwIS D. J. A taxonomic review of the genus Phlebotomus (Diptera : Psychodidae). Bulletin of the British Museum, Natural History (Entomology), 1982, 45, 121-209.

Lewis D. J. \& Buttiker W. Insects of Saudi Arabia, Diptera : family Psychodidae, subfamily Phlebotominae. Fauna of Saudi Arabia, 1980, 2, 252-285.

LEwis D. J. \& Buttiker W. Insects of Saudi Arabia. The taxonomy and distribution of Saudi Arabian phlebotomine sandflies (Diptera: Psychodidae). Fauna of Saudi Arabia, 1982, 4, 353-383.

Lewis D. J. \& Buttiker W. Some phlebotomine sandflies (Diptera : Psychodidae) from Saudi Arabia. Fauna of Saudi Arabia, 1986, 8, 324-339.

Maroli M., Gramiccia M. \& Gradoni L. Natural infection of Phlebotomus perfiliewi with Leishmania infantum in a cutaneous leishmaniasis focus in the Abruzzi region, Italy. Transactions of the Royal Society of Tropical Medicine and Parasitology, 1987, 81, 596-598.

Oumeish Y., Saliba E. and Allawi T. Cutaneous leishmaniasis an endemic disease in Jordan. Jordan Medical Journal, 1982, 16, 55-61.

Perfil'ev P.P. Phlebotomidae (Sandflies). Fauna of USSR, Diptera, 3, $\mathrm{n}^{\circ} 2$. Translated from Russian by the Israel Program for Scientific Translations, Jerusalem, 1968.

Saliba E.K., Oumeish O.Y., Haddadin J., Amr Z. \& Ashford R.W. Cutaneous leishmaniasis in Mowaqqar area, Amman Governate, Jordan. Annals of Tropical Medicine and Parasitology, 1985, 79, 139-146.

Saliba E., Saleh N., Bisharat Z., Oumeish O., Khouri S., Gramiccia M. \& Gradoni L. Cutaneous leishmaniasis due to Leishmania tropica in Jordan. Transactions of the Royal Society of Tropical Medicine and Hygiene, 1993, 87, 633

Schlein Y., Warburg A., Schnur L.F. \& Gunders A.E. Leishmaniasis in the Jordan Valley 2. Sandflies and transmission in the central endemic area. Transactions of the Royal Society of Tropical Medicine and Hygiene, 1982, 76, 582-586.

Theodor O. Psychodidae-Phlebotominae. Die Fleigen der Palaearktischen Region, 1958, 9c, 1-55.

Theodor O. \& Mesghali A. On the phlebotominae of Iran. Honolulu, Journal of Medical Entomology, 1964, 1, 258300.

WARBURG A. Characterization of zoonotic foci of leishmaniasis in southern Israel and identification of factors influencing the development of Leishmania major in Phlebotomus papatasi the sandfly vector. Thesis, Jerusalem (in Hebrew), 1986, (Cited by Jaffe et al., 1988). 